\title{
A Modified Richard's Equation for Assessing the Impact of Drought and Salinity in Arid and Semi-Arid Zones
}

\begin{abstract}
Drought and salinity onslaughts negatively affect plant physiological, morphological, and yield properties. We assumed that both drought and salinity cause the same effect on plant growth and yield properties. Accordingly, the additive effect was modeled. A modified formula of Richard's equation was created assuming the similar assumptions between the macroscopic model and soil stress index model. A split-split plot experimental design with four replications was used to conduct the research in Oraby Village, Maryout area, Alexandria, Egypt in the most dried year (2009/2010) to obsess the effect of silicon as a beneficial nutrient element on winter wheat especially under combined salinity and drought stresses. The response of wheat (Triticum Aestivium l.) cultivar, Sakha 94, to silicon doses added as potassium silicates and sodium silicates in three concentrations $0.0,30.6$ and 40.8 ppm silicon, was investigated. All of them were foliarly sprayed at ages of 45, 60 and 75 days from seed emergence at early morning. Moisture was tracked then the soil stress index model was derived, calculated, and discussed. The effective relative extreme response function between soil stress index and plant stress index was developed. The most interesting result is the ability of soil stress index to discriminate the type of water uptake under abiotic stresses conditions. It has been noticed that soil stress index is a new powerful managerial tool for assessing the environmental impact of managing abiotic stress with silica fertilization in the studied area in Egypt.
\end{abstract}

Keywords: Salinity Stress, Drought Stress, Modelling Soil Stress, Egypt, Arid and Semi-Arid Zones.

Abbreviations: SSI: Soil Stress Index- PSI: Plant Stress Index

\section{INTRODUCTION}

By the year 2030, the global climate change will be changing the half of the world's population lives to be in areas of water scarcity. In some arid and semi-arid regions, it will displace up to 24: 700 million people due to water stress problem (UN, 2010). Aridlands are characterized by the extreme lack of precipitation. Intensive heat waves during summers and severe cold below freezing point during winter, lack of renewable water resources and therefore the more dependency on the groundwater resources, high wind velocity, and accordingly the various forms of land degradation such as salinization, wind erosion, and desertification. (Gaur and Squires, 2018). United Nations (2010) chose the decade 2010-2020 for the fight against desertification. This is because the following reasons: $41.3 \%$ of the earth surfaces are drylands, approximately $44 \%$ of all the world's cultivated area located in the drylands. The desertification threats more than 1 billion people from the 2.1 billion people who live in the dry regions and responsible for an income loss of US $\$ 42$ billion per year.

Worldwide, Large areas of arid zones are located in north and south America, north African Sahara Desert $\left(9.1\right.$ million $\left.\mathrm{km}^{2}\right)$, the Sahelian region, Africa south of the Equator, the near east and the Asian Arabian desert in the Arabian Peninsula (2.3 million $\mathrm{km}^{2}$ ), and the Pacific regions between latitudes of 15 and $30^{\circ}$ in both northern and southern hemispheres (Fig. 1) (El Kateb, 2015 and FAO, 2020). In the most dried year, the cropping season 2009/2010, most of the world cropland faced a sever drought wave which affect the crop productivity especially where no renewable water resources exist. Most of MENA countries are located in arid zones. The problems of arid zones and their accompying results, salinization and desertification, are highlightened in the countries where no renewable water resources exist such as Libya (Zurqani et al., 2019). Saudia Arabia (Elhag, 2016) and Kwat (Alsulaili et al., 2022). Mapping and monitoring drought and salinity is vital to keep track and anticipate further degradation and essential for properly and timely interventions to adjust the managerial practices or undertake suitable reclamation and rehabilitation measures. (Nwer et al., 2013).

The irrigated salt-affected areas in Egypt which, are about nine hundred thousand hectares, distributed as follows: $60 \%$ is in the North of Delta, $20 \%$ in the South of Delta and Middle Egypt and $25 \%$ in the Upper Egypt. Wadi El-Natroun, Eltall El-Kebeir, the Oases, many parts of the Nile Delta and Valley, and El-Fayoum province are characterized as salt affected soils (Shaddad and Hendawi, 2018).

By manipulating the certain knowledge and technology which are currently available to use, the decision maker can solve many of the problems the

DOI: 10.21608/asejaiqjsae.2022.217756

${ }^{1}$ Ph.D. Natural Resources Department,

Faculty of African Postgraduate Studies, Cairo University, Giza, Egypt.

Received December 20, 2021, Accepted, February 06, 2022. 
world faces everytoday through the use of the available resources in a sustainable way (El Kateb, 2015). The limited water resources need latest technologies for managing the limited soil and water resources suitable for agriculture such as precise irrigation, low water quality recycling, desalinization of seawater, and foliar application of anti-transpirants and silicate fertilizers. Silicon, the second abundant element in the earth's crust (Chen, 2018), the beneficial nutrient element, is not inert but is involved in many metabolic and physiological processes inside the plant. Moreover, it deposits in root enhancing its elasticity, in tricombs enhancing its function in cooling leaves, in leaves increasing water use efficiency under optimal conditions (Elsokkary, 2018), and enhancing transpiration under sub-optimal condition. Silicon enhances the osmoregulation process which makes the suction head inside the plant's roots to be in a higher negative potential state to overcome the total potential of soil water. The silicaceous nutrition of plants is not only scientifically intriguing but also important in a world where more food will have to be wrung from a finite area of land especially for the deficit irrigation and partial root zone drying scenarios which will put crops under stress. (Epstein, 2009; Elkhatib et al., 2017).

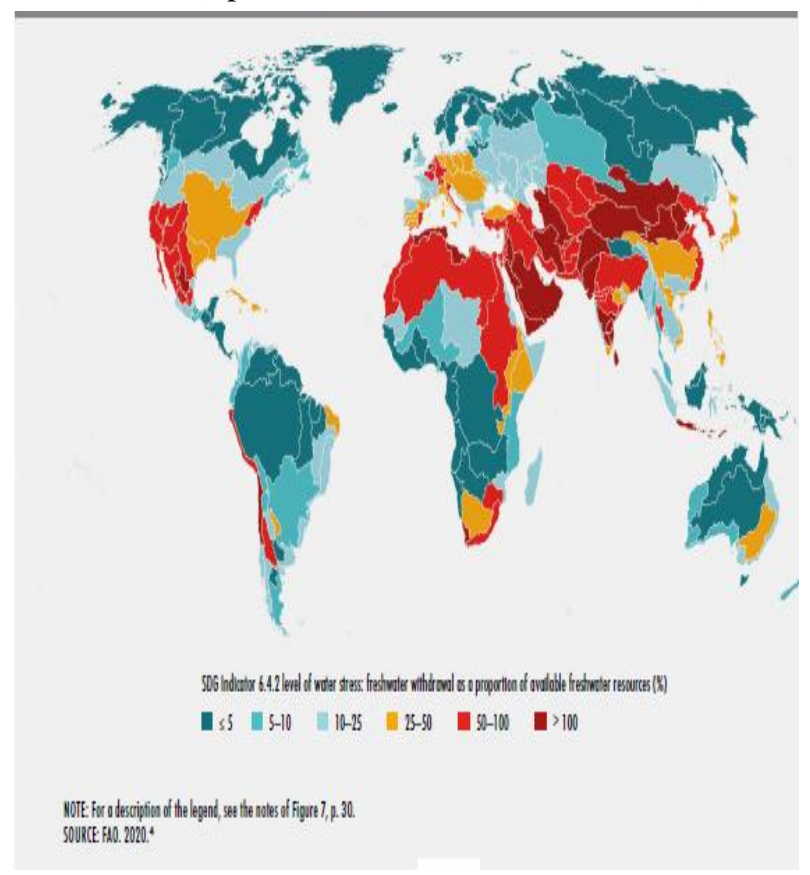

Figure 1. Worldwide level of water stress percentage at the year 2015 (FAO, 2020).

As soil available water decreases due to drought and salinity stress conditions, the agro-ecosystem components, plant and soil, start to do on their relative extreme response functions. The relative extremes may be achieved by root through choosing the easiest bath to navigate soil system, categorizing the energy states of soil water, preferring the easiest available water to water, and following model of minimizing the consumed energy for combating stress conditions. The interaction between ecosystem components, plant and soil; due to drought cycles, the soil is shrinking its energy now to the half of its value at the wetting cycles to save plant's life and prevent the hydrological release (Hegazy, 2020).

By limiting crown roots number per plant, plant causes a degree of response towards the drought stress, a compensatory growth in existing roots, which subsequently reaches deeper soil layers, categorizing the energy states of soil water seeking the easiest available water and nutrient for compensation. In tillering crops such as wheat, a drying soil was found to limit root growth at the top $30 \mathrm{~cm}$ using the hydraulic signal for increasing cell wall elastic modulus and maintaining turgidity while promoting root extension and growth into depth (Hegazy, 2020).

The objects of this research are as follow:

- Quantify the relationship between soil stress index and plant stress index under silicon foliar application as one of the effective managerial practices under the abiotic stress conditions of aridisols.

- Attach the soil stress index in Richard's equation instead of sink term to produce the modified Richard's equation.

- Discriminate between the types of water uptake by plant root under the stress conditions of aridisols.

\section{MATERIALS AND METHODS}

In the present investigation, a field experiment was carried out in Egypt as a major country in the African Sahara desert. An open field experiment was conducted at Oraby Village, Maryout area, Alexandria (Fig. 2) during the latest most drying year, 2009/2010. Wheat grains, Sakha 94, were sown on November 27th in all field experimental plots and harvested at the first week of May. Fertilization was managed according to the recommendations of ministry of agriculture in this year.

Drought and salinity were managed by the foliar spraying of silica products. The response of wheat to silicon doses was investigated by its addition as potassium silicates and sodium silicates in three concentrations $0.0,30.6$, and $40.8 \mathrm{ppm}$. All of them were foliar sprayed at ages of 45, 60, and 75 days from seed emergence at early morning. The 6 treatment combinations were distributed in 3 salinity levels, 3.12 , 4.82 , and $5.12 \mathrm{dS} / \mathrm{m}$, in a split-split plot design with four replicates. 


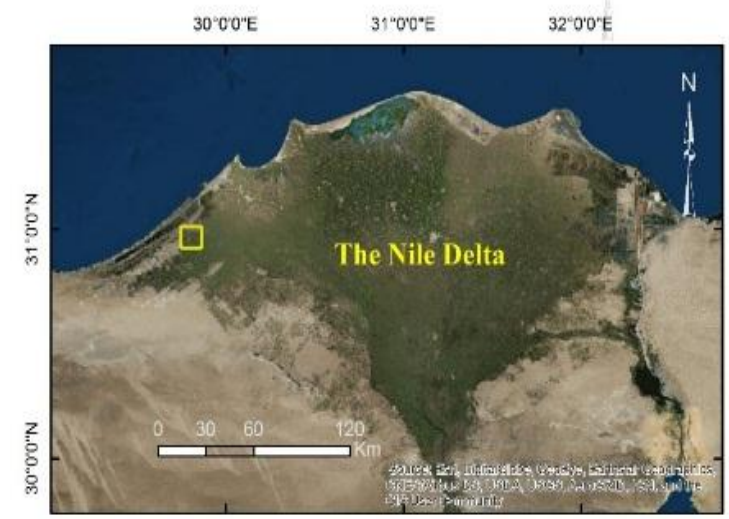

Figure 2. Location map of the studied area. Oraby Village appears as a yellow square. (Satellite image).

Soil hydro physical properties and water flow parameters were estimated by HYDRUS- 1D (Vr. 4.17) at depth $\mathrm{z}$ dimension (Simunek et al., 2013). ET $_{\mathrm{C}}$ was calculated from meteological data according to FAO (2002). The irrigation interval each 20: 25 day.

Soil moisture values were estimated gravimetrically in two dimensions $\mathrm{x}$ and $\mathrm{y}$ then converted to soil matric potential. The parallel soil electrical conductivity values were estimated in 1: 2.5 soil water extract and saturated soil paste following Jackson (1973) using EC meter, at $25^{\circ} \mathrm{c}$ then converted to soil osmotic potential. The soil total potential was calculated using the additive function taking into account the SI unites and prefixes which figurate the states of soil water at each day in the wetting drying cycles.

Daily SSI was estimated as a ratio between the daily energy states of soil water and the energy state of soil water at ideal condition. Daily PSI $=$ PSI (average) + PSI (average)* (dSSI/SSI)* Kc. Where dSSI: is the change of SSI between last two days and Kc: is the crop coefficient. PSI: is the ratio between actual and potential transpiration. Microsoft Excel was used for premodel the daily data of SSI and PSI. The FORTRAN programing language was used to model the relation between the applied soil stress and plant response functions which start to do on compensation according to.The compensation factor, $1 / \omega_{\mathrm{c}}$.

\section{The Soil Stress Index Model (SSIMOD)}

SSIMOD assumes that soil-moisture profile is as a series of capacitors (each of which representing water storage in a given layer), which are linked via the variable (potential-dependent) resistance of unsaturated Darcian flow. When current flows from the atmosphere downward (analogous to infiltration), it charges up the capacitors, causing soil wetting up. That storage is subsequently discharged by continued downward drainage beyond the bottom of the root zone or by upward flow in response to atmospheric evaporation of moisture from the soil surface. Each layer in the root zone is also discharged by roots present within it, and the water thus extracted flows toward and through the stem to the canopy and then to the atmosphere in the process of transpiration, now and then, each wettingdrying cycle (Hillel, 2002). The latter evapotranspiration is weather controlled by the water upward forces in plant and soil, the surface tension and capillarity (Fig. 3).

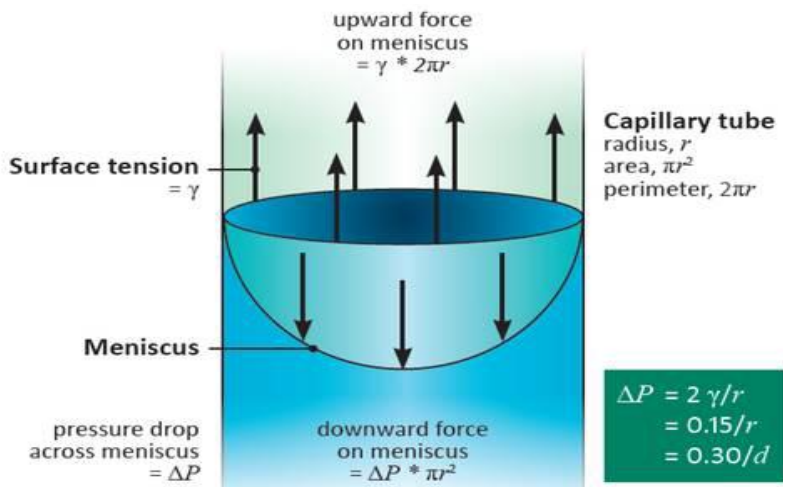

Figure 3. A fully-developed meniscus in a cylindrical tube showing the equality between the upward pull of surface tension and the downward pull of the suction in the water from which the relation $\Delta P=2 \gamma / r$ can be derived (Bazaraa et al., 2015).

Soil Stress Index Model (SSIMOD) is a new valuable managerial tool for assessing the impact of abiotic stresses of drought and salinity on water uptake by plant root. SSIMOD may discriminate the types of compensation during abiotic stresses periods. When SSIMOD gives a reliable data, it will be considered as a new hydro-physical property and will be widely used in vadoze zone management. SSIMOD could be derived as follow:

$$
\begin{aligned}
& \mathrm{SSI}=\lim _{\theta r \rightarrow 0}\left(\frac{S e}{S e \theta}\right) \quad \mathrm{Se}=\frac{\theta-\theta \mathrm{r}}{\operatorname{As}-\hat{A r}} \\
& \mathrm{SSI}=\lim _{\theta r \rightarrow 0}\left(\frac{\left(\frac{\theta-\theta \mathrm{r}}{\theta s-\theta \mathrm{r})}\right)}{\left(\frac{\theta *-\theta r}{\theta_{s}-\theta_{r}}\right)}\right) \quad \mathrm{SSI}=\lim _{\theta r \rightarrow 0}\left(\frac{\theta-\theta r}{\theta *-\theta r}\right) \\
& \theta=\theta_{\mathrm{mo}}+\theta_{\text {im }} \text { Dual Porosity theory (Fig. 4) } \\
& \theta_{\mathrm{r}} \leq \theta_{\mathrm{PWP}} \leq \theta_{\text {im }}
\end{aligned}
$$

Assume that the immobile moisture content is redundant in water flow researches and the soil moisture at permanent wilting point is redundant in root water uptake. The hydraulic parameter of Van-Genuchten n, $\mathrm{m}$, and $\alpha$ could be estimated if SSI is known (reverse solution) or from HYDRUS 1D (Tab. 1). 


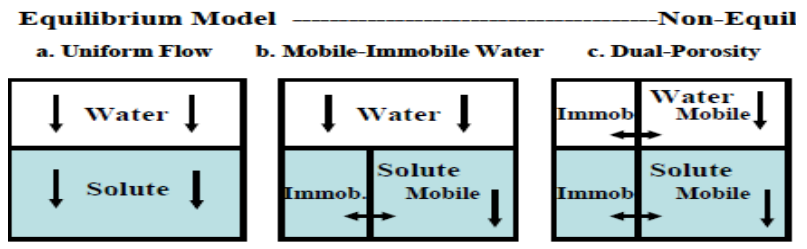

Figure 4. Conceptual physical nonequilibrium models for water flow and solute transport. (Simunek et al., 2013).

SSI $=\lim _{\theta i m \rightarrow 0}\left(\frac{\theta-0}{\theta *-0}\right)=\theta / \theta^{*}=\mathrm{h} / \mathrm{h}^{*}=\Psi / \Psi^{*}$

$\mathrm{S}_{\mathrm{e}}=\frac{\theta-\theta r}{\theta s-\theta r}=\left(1+(\alpha \Psi)^{\mathrm{n}}\right)^{\mathrm{m}}$

Similarly

$\mathrm{SSI}=\frac{\left(1+(\alpha \Psi)^{2}\right)^{\mathrm{m}}}{\left(1+(\alpha \psi s)^{2}\right)^{\mathrm{m}}} \quad(\mathrm{m}=1 / \mathrm{n})$

(Van Genuchten, 1980)

Table 1. Predicted soil hydro-physical properties according to HYDRUS 1D.

\begin{tabular}{lccc}
\hline & $\boldsymbol{\alpha}$ & $\mathbf{n}$ & $\mathbf{m}$ \\
\hline Clayey & 0.008 & 1.09 & 0.083 \\
Clayey Loam & 0.019 & 1.31 & 0.24 \\
\hline
\end{tabular}

$\mathrm{c}(\mathrm{h}) \frac{d h}{d t}=\frac{d}{d z}\left(k(h) \frac{d h}{d z}+k(h)\right)-S(z, t)$

$\mathrm{S}(\mathrm{z}, \mathrm{t})=\alpha(h, h s, z, t) \operatorname{Smax}$

$\mathrm{T}_{\mathrm{a}}(\mathrm{t})=\alpha(h, h s, t) \mathrm{T}_{\mathrm{p}}(\mathrm{t})$

$\mathrm{T}_{\mathrm{a}}(\mathrm{t}) / \mathrm{T}_{\mathrm{p}}(\mathrm{t})=\alpha(h, h s, t)$

$\mathrm{S}(\mathrm{z}, \mathrm{t}) / \mathrm{S}_{\max }=\alpha(h, h s, z, t)$

c(h) $\frac{d h}{d t}=\frac{d}{d z}\left(k(h) \frac{d h}{d z}+k(h)\right)-\alpha(h, h s, z, t) \operatorname{Smax}$

$\operatorname{SSI}(h, h s, z, t) . \alpha . \alpha(h, h s, z, t)$

$\operatorname{SSI}(h, h s, z, t)=\mu \alpha(h, h s, z, t)$

$\alpha(h, h s, z, t)=\frac{S S I(h, h s, z, t)}{\mu}$

$\mathrm{c}(\mathrm{h}) \frac{d h}{d t}=\frac{d}{d z}\left(k(h) \frac{d h}{d z}+k(h)\right)-\frac{S S I(h, h s, z, t)}{\mu} \operatorname{Smax}$

$\mathrm{SSI}=\frac{h(z, t)}{h *}$

$\mathrm{c}(\mathrm{h}) \frac{d h}{d t}=\frac{d}{d z}\left(K(h) \frac{d h}{d z}+K(h)\right)-\frac{h(z, t)}{(h *) u} \operatorname{Smax}$

$\omega=\frac{\operatorname{Smax}}{(h *) \mu} \quad \beta=\frac{\operatorname{Smax}}{\mu}$

c (h) $\frac{d h}{d t}=\frac{d}{d z}\left(K(h) \frac{d h}{d z}+K(h)\right)-\omega \mathrm{h}(\mathrm{z}, \mathrm{t})$

c (h) $\frac{d h}{d t}=\frac{d}{d z}\left(K(h) \frac{d h}{d z}+K(h)\right)-\beta$ SSI $(\mathrm{z}, \mathrm{t})$

$\beta \operatorname{SSI}(\mathrm{z}, \mathrm{t})=\frac{d}{d z}\left(K(h) \frac{d h}{d z}+K(h)\right)-\mathrm{c}(\mathrm{h}) \frac{d h}{d t}$
$\operatorname{SSI}(\mathrm{z}, \mathrm{t})=1 / \beta\left[\frac{d}{d z}\left(K(h) \frac{d h}{d z}+K(h)\right)-\mathrm{c}(\mathrm{h}) \frac{d h}{d t}\right]$

$\operatorname{SSI}(\mathrm{z}, \mathrm{t})=1 / \beta\left[\frac{d}{d z}\left(\mathrm{~K}(\mathrm{~h}) \frac{d h}{d z}+\mathrm{K}(\mathrm{h})\right)-\frac{d \theta}{d t}\right]$

$\operatorname{SS~I}(\mathrm{z}, \mathrm{t})=1 / \beta\left[\frac{d}{d z}\left(D(\theta) \frac{d \theta}{d z}+\mathrm{K}(\mathrm{h})\right)-\frac{d \theta}{d t}\right]$

Where Smax ,S: Potential yield and actual yield respectively. $\mathrm{h}^{*}$ : Total soil potential at field capacity (m). $h$ : Total soil potential at each point $\left(\mathrm{cm} \mathrm{H}_{2} \mathrm{O}\right) . \mathrm{T}$, $\mathrm{z}$ : Time and depth respectively (Day, $\mathrm{cm}), \mu$ : Direct proportional coefficient between SSI and $\alpha(h, \Psi)$ and can be estimated empirically. SSI: Soil stress index. $\alpha(h, \Psi)$ : Plant Stress Index. C: Soil water holding capacity $\left(\mathrm{cm}^{-1}\right)$. K: Hydraulic conductivity $(\mathrm{cm} /$ day). The water diffusivity function $\mathrm{D}(\theta)=\mathrm{k}(\theta) / \mathrm{c}(\theta)$

\section{RESULTS AND DISCUSSION}

\section{Soil Stress Index Model (SSIMOD)}

Modeling the water uptake response function depends mainly on the inherited soil moisture regimes Describing the abiotic stress in variably saturated zone with depth may be correlated by either a piecewise linear function of SSI (Z) (Eq. 1.1) or a stress reduction function of SSI $(z, t)$. (Fig. 5). These presentations are well reasonable due to these reasons: The effect of osmotic potential could be neglected. The amount of energy required to uptake water from the soil increases with decreasing matric potential. Water redistribution from surroundings to the root zone becomes small because of the limited hydraulic conductivity of the soil which depends on matric potential (Peters et al., 2017).

In the case of variably aerated zone of wetlands, the abiotic stress due to oxygen deficit does not depend on matric potential but volumetric air content and air filled porosity especially in fine-textured soil such as the soil under investigation (Peters et al., 2017). As a result, the water uptake in clayey and clayey loam soils in this zone may occur at a reduced rate over the entire range of water content due to the interaction between the limited aeration and low water potential stressors.

$$
\boldsymbol{f}(\mathbf{z})=\left\{\begin{array}{cc}
0.4074 \ln (\mathrm{znss})-0.5935, & 40>\mathrm{z}_{\mathrm{nss}} \geq 0 \\
0.9 & 100>\mathrm{z}_{\mathrm{nss}} \geq 40 \\
0.247 \ln (\mathrm{zss})-0.3727, & 45>\mathrm{z}_{\mathrm{ss}} \geq 0 \\
0.6 & 100>\mathrm{z}_{\mathrm{ss}} \geq 45 \\
\text { znss, zss: non saline soil and saline soil }
\end{array}\right.
$$

Similarly, in the case of salinity stress treatments studied in combinations with drought stress treatments, the osmotic potential should not be neglected but added 
to the matric potential to produce the total energy of soil water. The latter produces the additive stress reduction function (Fig. 5) which is well reasonable in studying the root response to water uptake under drought and saline conditions in variably saturated zone. SSI, as a conceptual index used the concept of total soil energy rather than matric potential in studying the stressors of drought and salinity either alone or incombination in vadoze zone.

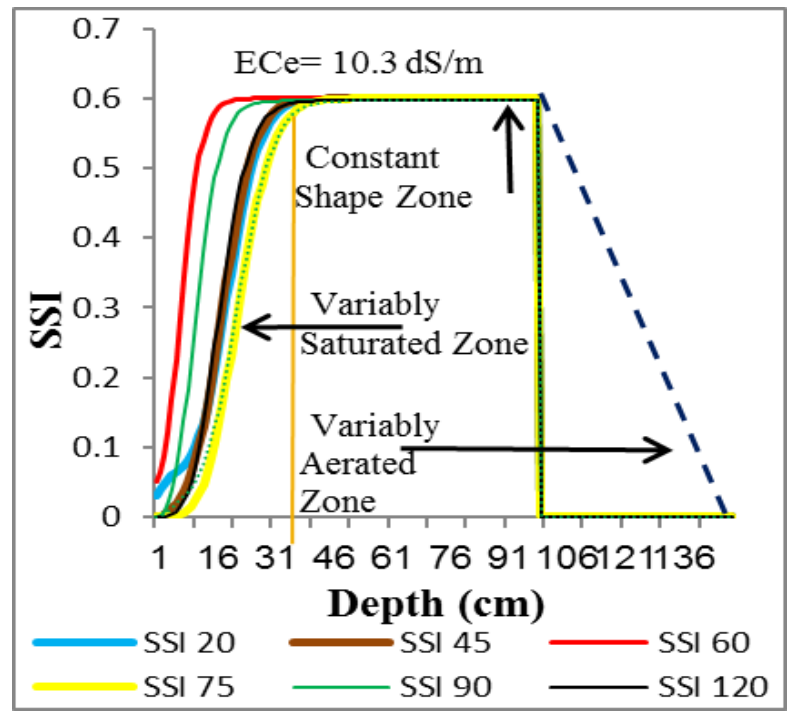

Figure 5. Soil stress index reduction function SSI $(z, t)$ for saline soil

In Figure (5), it has been assumed that no reverse flow uptakes the moisture from the subsoil and releases it into the dry topsoil observed in solid lines. The dashed line is imaginary to represent the variably aerated zone by replacing total soil water potential with volumetric air content.

SSIMOD should be compared by the other macroscopic solution of water uptake due to these reasons: the sensitivity of the macroscopic model under salinity stress condition is high (Clothier et al. 2006); the macroscopic models are empirical and they need to be calibrated with different plants, soils, and environmental climatic conditions (Homaee et al., 2002). The similar assumption of the macroscopic model and SSIMOD model is that the uptake takes place from the root zone as a whole not from the individual roots.

SIMOD, the electrical macroscopic model, is based on modified Richard's equation (Eqs. 1.2 and 1.3). The $\mathrm{S}$ sink/ source term depends on empirical response functions that describe plant water uptake based on a response to daily soil water potential $\mathrm{h}(\theta)$ which could be expressed as SSI (Eqs. 1.4 and 1.5). As soon as the data of daily SSI and PSI were estimated, an empirical regression response functions between them would be developed (Fig.6 and Tab. 2). When daily SSI with time and depth was incorporated in modified Richard's equation, $\beta$ coefficient would be the only unknown and it could be estimated by dividing $T_{P}$ over $\mu$ (Eq. 1.6). The latter could be empirically obtained from a regression equation amongst SSI and PSI (Tab. 2). Slope of the relation between SSI and PSI in the equations mentioned in Table (2) could be obtained by calculating the first order derivatives of these equations and could be considered as the synonyms of the proportional coefficient $(\mu)$ of the relationship between PSI and SSI the second order derivative of the function PSI $=\mathrm{f}(\mathrm{SSI})$ May reflect the hysteresis phenomenon between the two indices and it still under debate.

$\mathrm{c} \frac{d h}{d t}=\frac{d}{d z}\left(k \frac{d h}{d z}-k\right)-\mathrm{S}$
$\mathrm{c} \frac{d h}{d t}=\frac{d}{d z}\left(k \frac{d h}{d z}-k\right)-\beta . S S I$

Where S: sink/ source term $\left.\left(\mathrm{T}^{-1}\right)\right), \mathrm{t}, \mathrm{z}$ : time and depth respectively (T, L), SSI: dimensionless soil stress index, c: soil water holding capacity $\left(\mathrm{L}^{-1}\right), \mathrm{K}$ : unsaturated hydraulic conductivity (L/T).

The macroscopic solution could be obtained by direct substition in modified Rechard's equation as follows:

$$
\begin{aligned}
& \text { c } \frac{h 2-h 1}{\hbar 2-t 1}=\frac{1}{z 2-z 1}\left(k \frac{h 2-h 1}{z 2-z 1}-k\right)-\beta \text { SSI } \\
& \mathrm{SSI}=\frac{\left(1+(\alpha \Psi)^{2}\right)^{\mathrm{m}}}{\left(1+(\alpha \psi *)^{2}\right)^{\mathrm{m}}} \quad(\mathrm{m}=1 / \mathrm{n})
\end{aligned}
$$

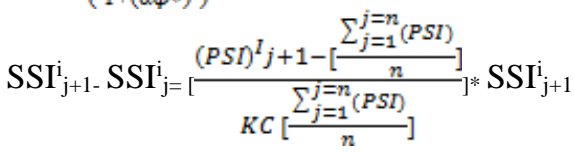

Water holding capacity $C(\theta)$ could be either observed, by calculating the slope of the soil moisture retention curve or predicted using HYDRUS 1D. Program. Similarly, unsaturated hydraulic conductivity $K(\theta)$ could be either experimentally observed using drop infiltrometer or predicted using HYDRUS 1D. program. As $\Theta, \mathrm{z}$, and $\mathrm{t}$ are pre-valued and SSI and $\mathrm{h}$ are modelled using the excel data sheet, the only unknown in Richard's equation is $\beta$, the soil hydroaulic capacitance (Eqs. 1.6 and 1.7).

On one hand, the coefficient $\beta$ represents the potential transpiration as the plant response toward the drought and salinity stresses reaches the unity. On the other hand, it represents the continuum's response capacitance and may distinguishe the type of compensation during the periods of abiotic stresses. It depends on the soil physical fertility, degree of plant tolerance, and metrological data. 
Table 2. Estimation of $\mu$, the proportional coefficient between PSI and SSI. The logarithmic relationship between the two indices.

\begin{tabular}{llcc}
\hline KSi & \multicolumn{1}{c}{ PSI $=\boldsymbol{f}$ (SSI) } & $\boldsymbol{\mu}=\mathbf{d P S I} / \mathbf{d S S I}$ & $\mathbf{R}^{\mathbf{2}}$ \\
\hline Log. & $\mathrm{y}=0.2044 \ln (\mathrm{x})-0.0169$ & $0.2 / \mathrm{x}$ & 0.95 \\
Poly. & $\mathrm{y}=-0.4607 \mathrm{x}^{2}+1.1165 \mathrm{x}-0.0819$ & $0.92 \mathrm{x}+1.1165$ & 0.9 \\
Lin. & $\mathrm{y}=0.555 \mathrm{x}+0.0462$ & 0.555 & 0.885 \\
NaSi & $\mathrm{PSI}=f(\mathrm{SSI})$ & $\mu=\mathrm{dPSI} / \mathrm{dSSI}$ & $\mathrm{R}^{2}$ \\
Log. & $\mathrm{y}=0.188 \ln (\mathrm{x})-0.0156$ & $0.188 / \mathrm{x}$ & 0.945 \\
Poly. & $\mathrm{y}=-0.4239 \mathrm{x} 2+1.0272 \mathrm{x}-0.075$ & $-0.8478 \mathrm{x}+1.03$ & 0.933 \\
Lin. & $\mathrm{y}=0.5106 \mathrm{x}+0.0425$ & 0.5106 & 0.885 \\
Cont. & $\mathrm{PSI}=f(\mathrm{SSI})$ & $\mu=\mathrm{dPSI} / \mathrm{dSSI}$ & $\mathrm{R}^{2}$ \\
Log. & $\mathrm{y}=0.1186 \ln (\mathrm{x})-0.0098$ & $0.1189 / \mathrm{x}$ & 0.936 \\
Poly. & $\mathrm{y}=-0.2672 \mathrm{x} 2+0.6476 \mathrm{x} 0.0475$ & $-0.5344 \mathrm{x}+0.65$ & 0.933 \\
Lin. & $\mathrm{y}=0.3219 \mathrm{x}+0.0268$ & 0.3219 & 0.885 \\
\hline
\end{tabular}

Equation (1.7) may be giving an indication about the maximum level of negative total soil water potential should be achieved by soil and water specialists to avoid the negative impacts of drought and salinity if it is higher than the plant tolerance. The ambiguity of coefficient $\beta$ needs further incoming researchs for nomination, calibration, validation, and parameterization especially under implementing the irrigation scenarios of deficit irrigation and partial root zone drying.

$\beta=\mathrm{Tp} / \mu$

$\beta=\mathrm{Tp} .(\mathrm{dSSI} / \mathrm{dPSI})$

[1.6]

$\beta=\operatorname{Tp} .\left(\frac{\mathrm{h} 2-\mathrm{h} 1}{\mathrm{~h} *} \cdot \frac{\mathrm{Tp}}{\mathrm{Tc} 2-\mathrm{Tc} 1}\right)$

$\beta=\operatorname{Tp} \cdot\left(\frac{\mathrm{h} 2-\mathrm{h} 1}{\mathrm{Tc} 2-\mathrm{Tc} 1} \cdot \frac{\mathrm{Tp}}{\mathrm{h} *}\right)$

$\beta=\operatorname{Tp} .\left(\frac{\mathrm{dh}}{\mathrm{dTc}} \cdot \frac{\mathrm{Tp}}{\mathrm{h} *}\right)$

Where: $\frac{\mathrm{Tp}}{\mathrm{h} \%}$ : represents the amount of potential transpiration from a unit volume of soil water potential at field capacity. Tp: represents the potential transpiration. $\frac{\mathrm{dh}}{\mathrm{dTc}}$ : represents the unit change of total soil water potential that causes a unit change in actual transpiration. $\beta$ : represents the coefficient of soil $\left(\mathrm{h}^{*}\right)$, plant $(\mathrm{Tc})$, and atmosphere (Tp) response capacitor. It distinguishes the type of compensation during the periods of abiotic stresses. It depends on the soil physical fertility, degree of plant tolerance, and metrological data. $\mathrm{h}^{*}$ : total soil potential at the ideal condition of plant growth and h: daily total soil potential which equal the summation of soil matric potential $h_{m}$ or $\Psi_{\mathrm{m}}$ and soil osmotic potential $\mathrm{h}_{\mathrm{s}}$ or $\Psi_{\mathrm{s}}$.
$\mathrm{Tc}=\mathrm{PSI} . \mathrm{T} \mathrm{p}=\beta . \mathrm{SSI}$

If $\mathrm{SSI}=\mathrm{PSI}$ then $\mathrm{T} p=\beta$ this means that soil moisture reservoir of the continuum hydraulic capacitance is able to meet the required potential transpiration and there is no stress and the uptake is uncompensated.

If $\mathrm{SSI}>\mathrm{PSI}$ then $\mathrm{Tp}>\beta$ this means that soil moisture resevior of the continuum hydraulic capacitance is unable to meet all the need of plant hydraulic machinery system. Plant roots respond to this moisture deficit by compensatory root growth for compensating water uptake from another layer which has higher soil moisture reservoir of the continuum hydraulic capacitance. This type of compensation is called partially compensated water uptake.

If $\mathrm{SSI}<$ PSI then $\mathrm{Tp}<\beta$ this means that soil moisture reservoir of the continuum's hydraulic capacitance is unable to meet all the need of plant hydraulic machinery system and there is another soil reservoir can recover the moisture deficit actually by compensated root growth for compensated water uptake. This type of compensation is called fully compensated water uptake. In the compensated water uptake, two layers with different hydraulic capacitance are combined to form a new layer holding much more continuum's hydraulic capacitance to compensate the moisture deficit either partially or fully due to the plant tolerance and atmospheric evaporative demands.

At the beginning of each irrigation cycle, SSI increases with any moisture content increase. The compensation starts to be partially at first by increasing the uptake by the factor of compensation $\left(1 / \omega_{c}\right)$ until the $\mathrm{Tp}=\mathrm{Tc}$. When it is possible, the mechanism of water uptake is changed to fully compensated water uptake. The latter may be expressed as follow: 
dSSI. $\mu=\mathrm{dPSI}=1 / \omega_{\mathrm{c}} \quad[1.9]$

Where

$\mu$ : first order derivative (Tab. 2).

dSSI: change in soil stress index.

dPSI: change in plant stress index.

$1 / \omega_{\mathrm{c}}$ : the compensation factor.

The root adaptability factor, $\omega \mathrm{c}$, represents the critical limit above which the reduced root water in waterstressed parts of the root layer is fully compensated by increased uptake from other soil layers that are less stressed. The obtained threshold value is synonym scientifically to that obtained by Simunek and Hopman (2009) but numerically it is still under research.

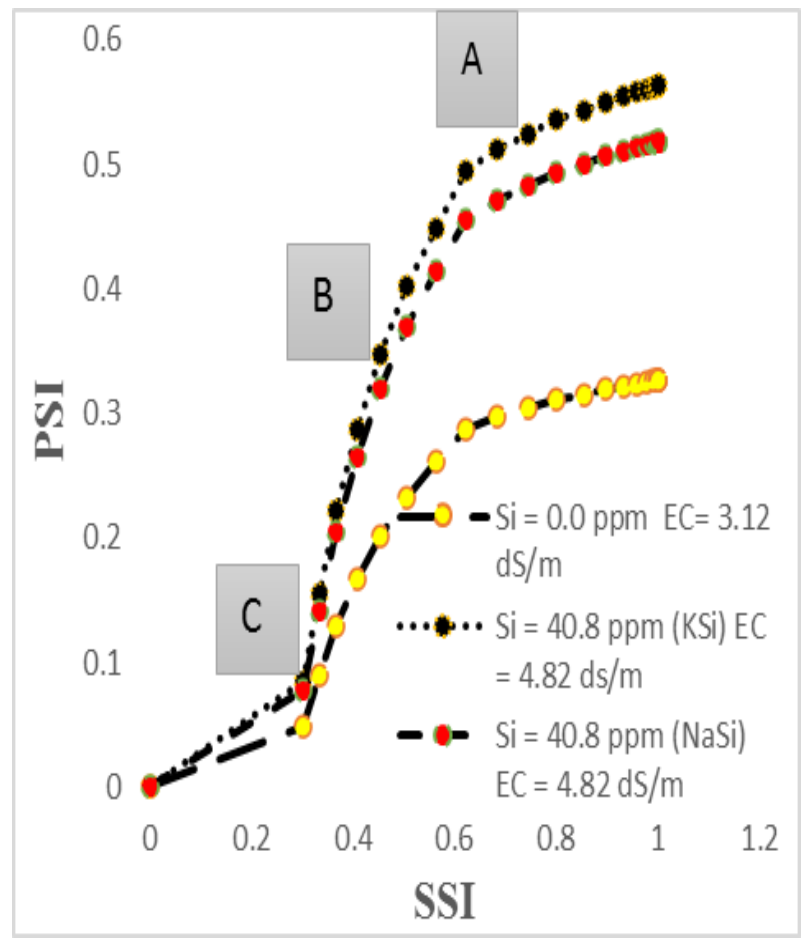

Figure 6. Variation of PSI with SSI at the first irrigation interval. $A: \mu$ at the end of compensation. $B: B=T p / \mu$ continuum's hydraulic capacitance. $C: \mu$ at the begining of compensation

When generalizing SSIMOD, which was developed under the Egyptian conditions of aridisols, some considerations should be taken into account. They are as follow:

- It should be calibrated under another similar environmental condition of aridisols such as in African Sahara desert in Libya and Asian desert of Arab peninsula in Kwait or Saudia Arabia.
- It should be verified in another different environmental conditions of aridisols such as USA and China.

- It should be verified in another soil moisture regime such as the saline Ethiopian highlands covering about 11 million hectares and extended in the most parts of the Great Rift Valley zone (Seid and Genenew, 2013).

- It should be verified under the saline and drought conditions in other soil orders mainly where the process silication or desilication takes place. On the other words, the podozolization formed Albic surface horizon in order spodosols such as in Russia and the latirization formed Oxic surface horizon in order Oxisols such as in Ethiopian highlands, respectively. Under such conditions the low of decreasing yield should be taken into consideration when plotting the relative extreme indices of soil and plant.

It is well known that in highly weathered soils, free $\mathrm{SiO}_{2}$ may become depleted from soils leaving sesquioxides of iron and aluminum' as the major residual minerals. In such soils, silica fertization is an effective managerial practices to achieve the optimal crop yields (Hegazy, 2020). Validating SSIMOD to be applied under wet Ethiopian highlands will develop a variably aerated root zone combined with salinity and gravity abiotic stressors instead of variably saturated root zone combined with salinity abiotic stress in the studied area in Egypt.

\section{CONCLUSION}

Soil genesis determines the adequate type of managerial practices to achieve the optimal yield. As a result of global climatic change, all soil orders in general and aridisols in particular may face the severe waves of drought and accordingly salinity which negatively affect root water uptake and consequently decrease yield. Better soil management under such conditions involves the use of silicon, the second abundant element in earth's crust, as a fertilizer for enhancing soil physical properties and plantation. A modified Richard's equation was derived, analyzed, and discussed to assess the latter impact. The relationship between PSI and SSI revealed the possibility of using SSI as an effective managerial tool for assessing the impact of soil drought and salinity on plant growth under silica fertilization. The relationship between PSI and SSI revealed the mechanism of water uptake as follow:

- Fully compensated uptake: PSI> SSI

- Uncompensated uptake: PSI=SSI

- Partially compensated uptake: PSI<SSI 


\section{REFERENCES}

Alsulaili, A., M. Alkandari and A. Buqammaz. 2022. Assessing the impacts of meteorological factors on freshwater consumption in arid regions and forecasting the freshwater demand. Environmental Technology \& Innovation 25, 102099. Available at https://doi.org/10.1016/j.eti.2021.102099.

Bazaraa, A., S. El-Ayouti and M. EL-Khader. 2015. Lectures in unsaturated zone hydrology, Faculty of Engineering, Cairo University.

Chen, D., Sh. Wang, L. Yin and X. Deng. 2018. How does silicon mediate plant water uptake and loss under water deficiency? Frontiers in Plant Science.9: 1-7.

Daliakopoulos, IN., IK. Tsanis, A. Koutroulis, N. Kourgialas, AE. Varouchakis, GP. Karatzas and CJ. Ritsema. 2016. The threat of soil salinity: A European scale review. Sci. Total Environ. 573:727-739.

Elhag, M. 2016. Evaluation of different soil salinity mapping using remote sensing techniques in arid ecosystems, Saudi Arabia. Journal of Sensors. 7596175,8. http://dx.doi.org/10.1155/2016/7596175

El Kateb, H. 2015. Sustainable forestry in desert lands of Egypt: Information Summary. German-Egyptian Collaboration to Afforestation in Desert Lands of Egypt: Information Summary and Description of the Field Experiments. Available online at www.karlgayer.de.

Elkhatib, H.A., S.M. Gabr, A.H. Roshdy and M.M. Abd AlHaleem. 2017. The Impacts of Silicon and Salicylic Acid Amendments on Yield and Fruit Quality of Salinity Stressed Tomato Plants. Alex. Sci . Exch. J. 38: 933-939.

Elsokkary, I.H. 2018. Silicon as a Beneficial Element and as an Essential Plant Nutrient: An Outlook. Alex. Sci . Exch. J. 39: 534-550.

Epstein, E. 2009. Silicon: its manifold roles in plants. Ann. Appl. Biol. 155: 155-160.

FAO. 2002. Crops and Drops: Making the Best Use of Water for Agriculture. Food and Agriculture Organization of the United Nations, Rome, Italy.

FAO. 2018. Somalia Emergency Drought and Recovery Project (SEDRP). Food and Agricultural World Organization of the United Nation, Rome, Italy. http://www.fao.org.

FAO. 2020. The State of Food and Agriculture 2020. Overcoming water challenges in agriculture. Food and Agriculture Organization of the United Nations, Rome, Italy. http://www.fao.org/publications.
Gaur, M.K and V.R. Squires. 2018. Geographic extent and characteristics of the world arid zones and their peoples.Available https://www.researchgate.net/publication/319404633.

Green, S.R., M.B. Kirkham and B.E. Clothier. 2006. Root uptake and transpiration from measurements and models to sustainable irrigation. Agric.W. Mang. 86: 165- 176.

Hegazy, El-Sh. 2020. Modelling the response of root uptake to silicon foliar application under drought and saline conditions in Egypt and Libya. Ph. D. Thesis, Faculty of African Post Graduate Studied, Cairo University.

Hillel, D. 2002.Environmental of Soil Physics. Academic Press Inc., New York, 550 p.

Homaee, M., R. A. Feddes and C. Dirksen. 2002. Simulation of root water uptake. П Non- uniform transient water stress using different reduction functions. Agric. W. Mang. 57:111- 126.

Nwer, B., H. Zurqani and K. Jadour. 2013. Soil productivity rating index model using geographic information system in Libya. In Proceedings of the Annual International Conference 7th Edition of Geotunis, Southern Hammamet, Tunis. 4-12.

Peters, A., W. Durner and S. C. Iden. 2017. Modified Feddes type stress reduction function for modelling root water uptake: Accounting for limited aeration and low water potential. Agric. Water Manag. 185: 126- 136.

Simunek, J., M. Sejna, H. Saito, M. Sakai and M. Th. Van Genuchten. 2013.The HYDRUS-1D Software Package for Simulating the One-Dimensional Movement of Water, Heat, and Multiple Solutes in Variably-Saturated Media. Version 4.17. Available at Department of Environmental Sciences University of California Riverside, p. 240. Available online at: https://www.pc-progress.com.

Simunek, j and J.W. Hopmans. 2009. Modelling compensated root water and nutrient uptake. Ecological Modelling. 22: 505-521.

UN. 2010. United Nation Decade, 2010-2020, for desert and the fight against desertification. Available at http://www.un.org/en/events/desertification_decade/whyn ow.shtml

Van-Genuchten, M. Th. 1980. A closed-form equation for predicting the hydraulic conductivity of unsaturated soils, Soil Sci. Soc. Am. J. 44:892-898.

Zurqani, H. A., E. A. Mikhailova, Ch. J. Post, M. A. Schlautman and A. R. Elhawej. 2019. A Review of Libyan soil databases for use within an ecosystem services framework. Land. 82:19- 22. 


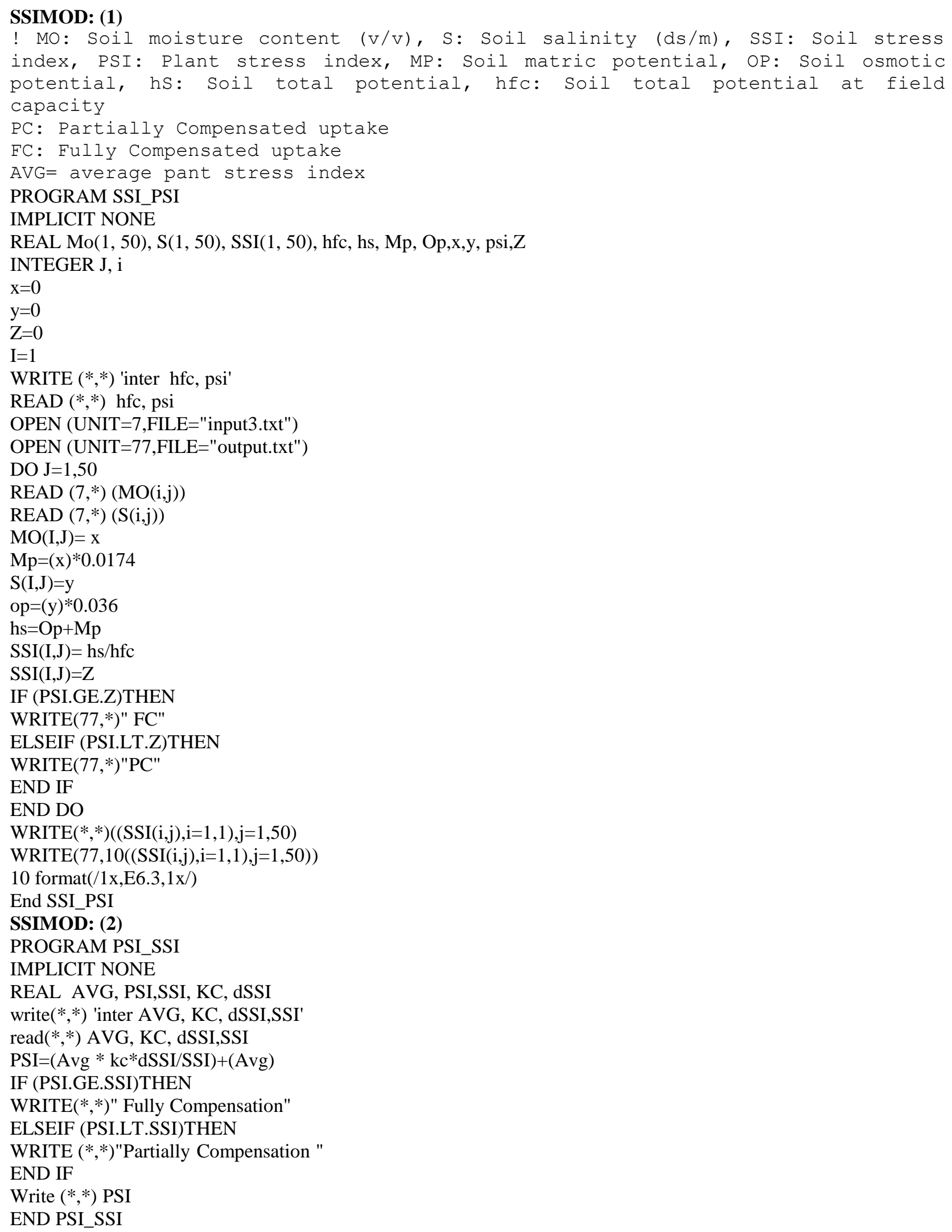




\section{الملخص العريي}

تحوير فى معادلة ريتشارد لتقيم أثر أجهادات الملوحة والجفاف على نمو النبات فى النطاقات الجافة وشبه

الجافة

الثاذلى محمد حجازى

الاوراق بعد 0؛، ، 7، V0 يوما من إنبات البذور وذللك فى الصباح الباكر • وقد وزعت هذه المعاملات الست على ثلاتلثة مستويات من ملوحة التربة وذلك من خلال قطع منشقة مرنين ذات أربعة مكررات. تم تتبع الرطوبه فى قطاع التربه والتطبيق فى النموذج الرياضى بعد أشنقاقه لحساب دليل الاجهاد الارضى. تم الحصول على العلاقه التى تربط بين

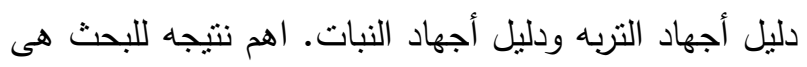

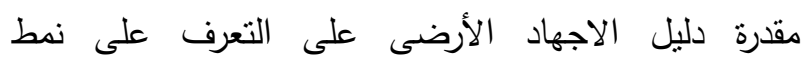

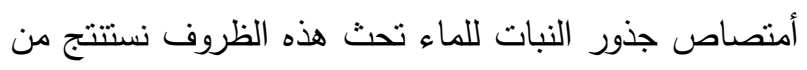

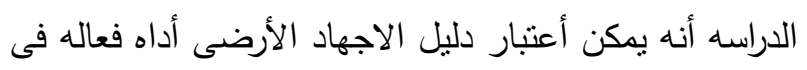
تقييم تأثيرات الملوحة والجفاف على النبات النامى فى منطقة أجراء البحث.

الكلمات المفتاحية:اجهاد الملوحة، اجهاد الجفاف، نمذجة اجهاد التربه، مصر ، النطاقات الجافة وشبه الجافة.
الملوحة والجفاف تؤثران سلبيا على صفات النبات الفسيولوجية والمورفولوجية وأنتاجية المحصول. تم أفتراض أن

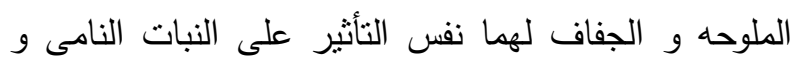
بالتالى تم أستخدام التأثير التجميعى لهما فى نمذجة تأثنرهما

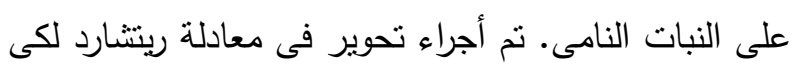
تتضمن دليل الاجهاد الأرضى وذلك بأفتراض مجموع جذرى تعاونى. تهدف الدراسة الى أشنقاق وتحليل أداه جديده لتقييم أثز الملوحة والجفاف تحت ظروف الرش بالسليكون. أجريت تجربة حقلية فى الأراضى الجيرية بقرية عرابى بمنطقة مريوط

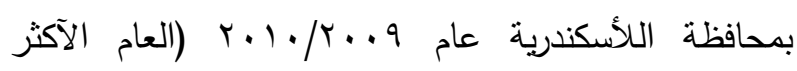
جفافا) لدراسة تأثير الرش بعنصر السليكون على نمو

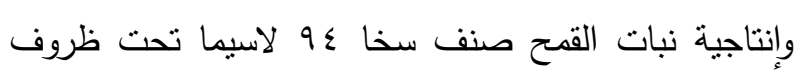
إجهاد مركب من الملوحة والجفاف. تم إضافة السليكون فى صورة سليكات الصوديوم وسليكات البوتاسيوم كل منهما

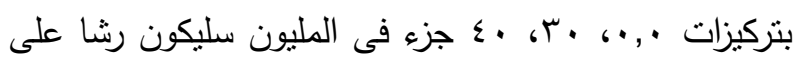

